\title{
The development of an integrated assessment instrument for measuring analytical thinking and science process skills
}

Irwanto, Eli Rohaeti, Endang Widjajanti LFX, and Suyanta

Citation: AIP Conference Proceedings 1847, 050005 (2017); doi: 10.1063/1.4983907

View online: http://dx.doi.org/10.1063/1.4983907

View Table of Contents: http://aip.scitation.org/toc/apc/1847/1

Published by the American Institute of Physics

\section{Articles you may be interested in}

An integrated assessment instrument: Developing and validating instrument for facilitating critical thinking abilities and science process skills on electrolyte and nonelectrolyte solution matter

AIP Conference Proceedings 1847, 050007 (2017); 10.1063/1.4983909

Opportunity integrated assessment facilitating critical thinking and science process skills measurement on acid base matter

AIP Conference Proceedings 1847, 050006 (2017); 10.1063/1.4983908

Confirmatory factor analysis of teaching and learning guiding principles instrument among teacher educators in higher education institutions

AIP Conference Proceedings 1847, 060001 (2017); 10.1063/1.4983911

TGT for chemistry learning to enhance students' achievement and critical thinking skills

AIP Conference Proceedings 1847, 050002 (2017); 10.1063/1.4983904

Who is more efficient: Teacher or pedagogical agents?

AIP Conference Proceedings 1847, 050001 (2017); 10.1063/1.4983903

Development of monograph titled "augmented chemistry aldehida \& keton" with 3 dimensional (3D) illustration as a supplement book on chemistry learning

AIP Conference Proceedings 1847, 050003 (2017); 10.1063/1.4983905 


\title{
The Development of an Integrated Assessment Instrument for Measuring Analytical Thinking and Science Process Skills
}

\author{
Irwanto $^{1, \text { a) }}$, Eli Rohaeti ${ }^{2, b)}$, Endang Widjajanti LFX ${ }^{3}$, Suyanta $^{3}$ \\ ${ }^{1}$ Doctoral Student in Educational Science, Yogyakarta State University, Yogyakarta, Indonesia \\ ${ }^{2}$ Department of Chemistry Education, Yogyakarta State University, Yogyakarta, Indonesia \\ ${ }^{3}$ Department of Chemistry, Yogyakarta State University, Yogyakarta, Indonesia \\ ${ }^{a)}$ Corresponding author: Irwanto.2016@student.uny.ac.id \\ b)Eli_rohaeti@uny.ac.id
}

\begin{abstract}
This research aims to develop instrument and determine the characteristics of an integrated assessment instrument. This research uses 4-D model, which includes define, design, develop, and disseminate. The primary product is validated by expert judgment, tested it's readability by students, and assessed it's feasibility by chemistry teachers. This research involved 246 students of grade XI of four senior high schools in Yogyakarta, Indonesia. Data collection techniques include interview, questionnaire, and test. Data collection instruments include interview guideline, item validation sheet, users' response questionnaire, instrument readability questionnaire, and essay test. The results show that the integrated assessment instrument has Aiken validity value of 0.95 . Item reliability was 0.99 and person reliability was 0.69 . Teachers' response to the integrated assessment instrument is very good. Therefore, the integrated assessment instrument is feasible to be applied to measure the students' analytical thinking and science process skills.
\end{abstract}

\section{INTRODUCTION}

Assessment is one of important parts of learning process. Assessment relates to the objectives and learning process. A learning process includes planning, implementation of learning process, assessment of learning outcomes, and students follow up assessment [1]. A good learning will not be successful without a good assessment. Assessment is expected to reflect the ability of students as a whole, both in terms of knowledge, attitudes, and skills [2-3] and able to stimulate the students to optimize their potential [4-5]. Therefore, learning process and learning outcomes assessment are two components that cannot be separated.

One of the learning activities which can train the students' ability in developing those three competencies is internship activities in the laboratory [6]. Practical activities in laboratory can motivate students to develop a number of important processes skills. One of the most important skills for students in the $21^{\text {st }}$ century is science process skills [7]. Moreover, in order to acquire laboratorial experience, practical cannot be separated from chemistry learning, investigation experience, improvement attitude toward chemistry, and science process skills [8].

Science process skill is a cognitive skill that can be measured by using written test [9]. This condition arises because science process skills relates to the cognitive domains of the students which includes the analytical thinking ability [10]. One of the assessments which uses written test is essay. The advantage of essay test is that they are capable of measuring various aspects of the science process skills of the students, hence the essay has the potential to be developed as an instrument of science process skills assessment. Achievement test is able to provide information which describes the ability of the students [11].

On the other hand, assessment of the students' learning outcomes on cognitive and psychomotor aspects often presents various problems. One of the problems which often occur is that the teacher chooses the form of classroom assessment without considering of how they assess and what will be assessed [12]. In addition, an assessment of the

Proceedings of the International Conference on Education, Mathematics and Science 2016 (ICEMS2016) in

Conjunction with 4th International Postgraduate Conference on Science and Mathematics 2016 (IPCSM2016) AIP Conf. Proc. 1847, 050005-1-050005-6; doi: 10.1063/1.4983907

Published by AIP Publishing. 978-0-7354-1519-5/\$30.00 
science process skills has not been optimally implemented by the teachers. The ability of teachers to prepare and conduct an assessment is still lacking; in fact, there are many teachers who do not yet have sufficient understanding of the scoring system [13]. Moreover, the learning outcome instruments used by the teacher for daily test or used by the school for general tests are not yet qualified as a good test [14].

Generally, the teacher presents a question which dominantly uses short answers and only covers narrow scale of remembering, understanding, and applying, making the students ability only used to solve on lower level cognitive problems [15]. In relation to the assessment of the students' ability, the short answer test at the level of lower level cognitive only capture a small portion of students' skill and intelligence [16]. Whereas in the $21^{\text {st }}$ century, the students are required to master not only lower order thinking skills, but also to the higher order thinking skills.

One of higher order thinking skills is the analytical thinking. Analytical thinking is not all about memorizing facts, but efforts to improve complex and creative understanding to achieve a better learning objective. Analytical thinking ability is a higher level of cognitive which can be achieved by the students after mastering lower level cognitive domain such as remembering, understanding, and applying. To evaluate the level of analytical thinking, it is needed a standardize learning outcome instrument which can also be utilized to measure science process skill through integrated laboratorium activity. This condition needs to be carried out since effective laboratory activity can develop intellectual ability, scientific inquiry, and problem solving ability of the students [17].

Based on these descriptions, it is necessary for the preparation of an integrated assessment instrument that can be used to measure analytical thinking objectively, as well as cover various aspects of science process skills in chemistry practical learning in laboratory.

\section{RESEARCH METHODS}

This research model is a procedural development research, which is a descriptive research, showing the steps which have to be followed to produce the final product. This type of research is an education research and development (R\&D). This research uses 4-D (four-D) model which was developed by Thiagarajan, Semmel \& Semmel [18]. 4-D model consists of four main stages, which are define, design, develop, and disseminate. Education research and development is a method used to produce products in the field of education in the form of an evaluation tool, and then to test the validity, practicality, and effectiveness of the product.

This research and development was conducted on September $5^{\text {th }}-$ December $25^{\text {th }} 2015$. The research sites were four senior high schools (SMA) in Yogyakarta, Indonesia. Research location selection was determined by purposive sampling techniques based on school ranking (high, medium, and low) according to the results of chemistry National Examination (UN ) 2015. The subjects involved 246 students of grade XI academic year of 2015/2016. The subjects cover the students of SMA 2 Yogyakarta, SMA 4 Yogyakarta, SMA 6 Yogyakarta, and SMA 10 Yogyakarta. The allocation of time used in the empirical test is 90 minutes.

The types of data are feasibility and characteristics instrument data. Feasibility data of the integrated assessment instrument were obtained from validation by judgment expert, feasibility of chemical products by the chemistry teacher, and the instrument readability test by the students. Whereas the instrument characteristic data were obtained from the empirical test. The types of data collection instruments include interviews guideline, validation items sheet, users' response questionnaire, instrument readability questionnaire, and essay test. Data analysis techniques are qualitative and quantitative.

Data were analyzed using quantitative descriptive approach in accordance with the statistical methods used then interpreted. Initial data obtained were the items validation result data by expert judgment. Data analysis of the validation item result used rules of score conversion as seen in Table 1.

Table 1. Score Conversion [19]

\begin{tabular}{ccc}
\hline No. & Score Interval & Category \\
\hline 1 & $\geq 3.00$ & Very Good \\
2 & $3.00>X \geq 2.50$ & Good \\
3 & $2.50>X \geq 2.00$ & Poor \\
4 & $<2.00$ & Very Poor \\
\hline
\end{tabular}

After the items are validated and assembled into the test, the next step is scoring product by the chemistry teacher using Likert scale as seen in Table 2. 
Table 2. Scoring Rules

\begin{tabular}{ccc}
\hline No & Category & Score \\
\hline 1. & Very Good & 5 \\
2. & Good & 4 \\
3. & Average & 3 \\
4. & Poor & 2 \\
5. & Very Poor & 1 \\
\hline
\end{tabular}

The final scores then were converted into product feasibility as seen in Table 3.

\begin{tabular}{|c|c|c|}
\hline No & Score Interval & Category \\
\hline 1. & $4.20 \leq$ & Very Good \\
\hline 2. & $3.40 \leq \bar{X}<4.20$ & Good \\
\hline 3. & $2.60 \leq \bar{X}<3.40$ & Average \\
\hline 4. & $1.80 \leq \bar{X}<2.60$ & Poor \\
\hline 5. & $<1.80$ & Very Poor \\
\hline
\end{tabular}

After the instrument feasibility was assessed by chemistry teachers, the next step is conducting readability test to the students. Data of instrument readability which was obtained from students responses are shown in Table 4.

Table 4. Qualitative Conversion

\begin{tabular}{clc}
\hline No. & \multicolumn{1}{c}{ Options } & Score \\
\hline 1. & Strongly Agree & 4 \\
2. & Agree & 3 \\
3. & Disagree & 2 \\
4. & Strongly Disagree & 1 \\
\hline
\end{tabular}

The final score which was obtained from all students are then converted into the product feasibility as seen in Table 1.

\section{RESULTS AND DISCUSSION}

\section{The Validity of Test Item Data}

All items are validated by a professor and a senior lecturer from Graduate School of Yogyakarta State University, who have ability in chemistry education. In addition, the item also validated by three chemistry teachers who are expert in items preparation. The objective of item validation is to determine the match between item which was developed by learning indicator, analytical thinking, and science process skills. The indicator of analytical thinking includes the ability of the students in differentiating, organizing, and attributing. The indicator of science process skills include the ability of the students in designing experiment, predicting, classifying, interpreting, measuring, inferring, applying concept, constructing graphs, and communicating. Based on Table 1, the result of item validation is shown in Table 5 .

Table 5. Item Validation Results

\begin{tabular}{clcl}
\hline No. & Expert Judgment & Score & Category \\
\hline 1. & Evaluation Specialist & 3.93 & Very Good \\
2. & Content Specialist & 3.67 & Very Good \\
3. & Chemistry Teachers & 3.89 & Very Good \\
\multicolumn{2}{l}{ Average } & 3.83 & Very Good \\
\hline
\end{tabular}

Max. Score $=4.00$

The validity of item was calculated by using Aiken's V formula. The result shows that the highest and lowest validity are 1.00 and 0.73 . The average of item validity index is 0.95 which is very high category. Based on results analysis of the expert it is concluded that there are 12 items with a very high validity $(80 \%)$ and 3 items with high validity $(20 \%)$. 
The other results from items validity is in the form of improvement suggestion for the instrument from expert judgment. Instrument improvement was mainly applied on writing technique and language used which can a rise confusion and difficulty to the students in understanding the question. It is important since sentence mistake is a factor that can influence test performance.

\section{The Validity of Instrument Readability Questionnaire Data}

The validity of instrument readability questionnaire was obtained from assessment by using validity sheet of instrument readability questionnaire which was conducted by content and evaluation specialist. Based on Table 1, validation results of instrument readability questionnaire is shown in Table 6.

\begin{tabular}{llcc}
\multicolumn{4}{c}{ Table 6. Readability Questionnaire Validation Results } \\
\hline No. & Expert Judgment & Score & Category \\
\hline 1. & Evaluation Specialist & 3.87 & Very Good \\
2. & Content Specialist & 4.00 & Very Good \\
& Average & 3.93 & Very Good \\
\hline
\end{tabular}

Max. Score $=4.00$

The validity of instrument readability questionnaire was calculated by Aiken's V formula. Based on analysis results of content and evaluation specialist, it is concluded that all items have very high validity (100\%). The calculation result shows that the highest and the lowest validity are 1.00 and 0.83 . Validity index average of instrument readability questionnaire is 0.95 which is very high.

\section{The Validity of Users' Response Questionnaire Data}

The validity of users' responses questionnaire is obtained from scoring sheet of responses questionnaire which was applied by content and learning evaluation specialist. The validation was conducted by giving accurate score in every statement item. Based on Table 1, the validation results of users' responses questionnaire is shown in Table 7.

Table 7. Users' Response Questionnaire Validation Results

\begin{tabular}{clcc}
\hline No. & Expert Judgment & Score & Category \\
\hline 1. & Evaluation Specialist & 3.88 & Very Good \\
2. & Content Specialist & 4.00 & Very Good \\
\multicolumn{2}{c}{ Average } & 3.94 & Very Good \\
\hline
\end{tabular}

Max. Score $=4.00$

The validity of users' responses questionnaire was calculated by using Aiken's $\mathrm{V}$ formula. Based on result analysis from content and evaluation specialist, it is concluded that every item in response questionnaire has a very high validity $(100 \%)$. The result shows that the highest and lowest validity are 1.00 and 0.83 . Validity index average of instrument readability questionnaire is 0.98 which is very high category.

\section{Instrument Readability Test Data}

The readability test involved 58 students of SMA 2 Yogyakarta and SMA 10 Yogyakarta. The aim of the readability test is to determine the understanding level of the students to the use of language, picture, table, graphic, content, and instruments display. Based on Table 1, the results of instrument readability test is shown in Table 8 .

Table 8. Instrument Readability Test Results

\begin{tabular}{clcc}
\hline No. & Components & Score & Category \\
\hline 1 & Didactic & 3.31 & Very Good \\
2 & Construction & 3.11 & Very Good \\
3 & Technical & 3.17 & Very Good \\
& Average & 3.14 & Very Good \\
\hline
\end{tabular}

Max. Score $=4.00$

Table 8 shows that most of the students give strongly agree respond to all aspect which was measured in instrument readability questionnaire. It shows that the use of language, picture, table, graphic, or content presented in instrument can be understood easily by the students and feasible to be field tested. 


\section{Product Assessment Data}

The aims of initial product assessment by reviewer is to determine more input to perfect the instruments which have been developed. The reviewers who conducted product assessment are teacher from MA 1 Yogyakarta, SMA 2 Yogyakarta, SMA 4 Yogyakarta, and SMA 10 Yogyakarta. The instrument assessment by reviewers cover five feasibility components which are described into 24 criteria. Based on Table 3, response of integrated assessment instrument data is shown in Table 9.

Table 9. Instrument Feasibility Results

\begin{tabular}{clcc}
\hline No. & Components & Score & Category \\
\hline 1. & Substance & 4.50 & Very Good \\
2. & Construction & 4.40 & Very Good \\
3. & Language & 4.48 & Very Good \\
4. & Validity & 4.53 & Very Good \\
5. & Practicability & 4.27 & Very Good \\
& Average & 4.44 & Very Good \\
\hline
\end{tabular}

Max. Score $=5.00$

\section{Instrument Test Results Data}

Estimation reliability can be obtained through item separation index (item reliability) as well as person separation index (test reliability). Reliability of the test refers to the consistency of the scores achieved by the students when tested repeatedly using the same test on different occasions. Based on an analysis of 15 trials empirical item using Winsteps program generates estimates of the sample reliability of 0.99 and test reliability of 0.69 . In other words, all items in the final product expressed empirically reliable. Therefore, the integrated assessment instrument is feasible to be applied to measure students' analytical thinking and science process skills effectively and efficiently.

\section{CONCLUSIONS AND SUGGESTIONS}

Based on the results of data analysis has been done, can be concluded that the process of development of instrument using 4-D model, which includes the step define, design, develop, and disseminate. The results show that the integrated assessment instrument has Aiken validity value of 0.95 . Item reliability was 0.99 and person reliability was 0.69 . Teachers' response to the integrated assessment instrument is very good. Therefore, the integrated assessment instrument is feasible to be applied to measure students' analytical thinking and science process skills. Based on these conclusions, the teachers need to improve the quality of learning by developing the students' analytical thinking and science process skills. Instrument development results are expected to be used as guidelines for teachers to prepare similar instruments in other chemical materials. Furthermore, the need for training on the preparation of integrated assessment instrument for chemistry teachers.

\section{ACKNOWLEDGMENT}

The authors would like to express profound thanks and appreciation to the DP2M DIKTI (Directorate of Higher Education), Ministry of Research, Technology and Higher Education Republic of Indonesia through "Tim Pascasarjana" Research Grant 2016 for the financial support.

\section{REFERENCES}

1. I. Waluyati, Jurnal Penelitian dan Evaluasi Pendidikan 16, 260-280 (2012).

2. B. A. Wallace and J. E. Truelova, Journal of Cognitive Affective Learning 3, 22-27 (2006).

3. E. O. Crawford and M. M. Kirby, Journal of Curriculum and Instruction 2, 56-73 (2008).

4. L. R. Ketterlin-Geller, Journal of Technology, Learning, and Assessment 4, 1-22 (2005).

5. M. Abell, Journal of Technology, Learning, and Assessment 5, 1-20 (2006).

6. D. Donnelly, J. O’Reilly, and O. McGarr, Res. Sci. Educ. 43, 1571-1592 (2013).

7. S. Areesophonpichet, Proceeding of the Asian Conference on Education, Osaka, Japan, 2013, pp. 1-15. 
8. E. Susilaningsih, Jurnal Penelitian dan Evaluasi Pendidikan 16, 234-248 (2012).

9. B. Subali, Jurnal Cakrawala Pendidikan 15, 130-144 (2011).

10. S. Özgelen, Eurasia J. Math. Sci. \& Tech. Ed. 8, 283-292 (2012).

11. S. C. Bauer, Journal of Education Policy Analysis Archives 46, 1-18 (2000).

12. I. H. Wenno, Jurnal Cakrawala Pendidikan 29, 176-188 (2010).

13. S. Suwandi, Model Asesmen dalam Pembelajaran (Yuma Pustaka, Surakarta, 2011), p.2.

14. D. Mardapi, Kumaidi, and B. Kartowagiran, Jurnal Penelitian dan Evaluasi Pendidikan 15, 326-341 (2011).

15. B. D. Kulkarni and V. D. Tendolkar, Journal of Health Sciences Education 2, 43-47 (2015).

16. Murtono and E. Miskiyah, Jurnal Inovasi dan Pembelajaran Fisika 1, 1-12 (2014).

17. E. M. Stone, CBE-Life Sciences Education 13, 90-101 (2014).

18. S. Thiagarajan, D. Semmel, and M. Semmel, Instructional Development for Training Teachers of Exceptional Children: A Sourcebook (University of Minnesota, Minneapolis, 1974), p.5.

19. D. Mardapi, Pengukuran, Penilaian, dan Evaluasi Pendidikan (Nuha Medika, Yogyakarta, 2012), p.162.

20. E. P. Widoyoko, Evaluasi Program Pembelajaran (Pustaka Pelajar, Yogyakarta, 2009), p.239. 